\title{
Age and gender effects of workforce composition on productivity and profits: Evidence from a new type of data for German enterprises
}

\author{
Christian Pfeifer ${ }^{1}$, Joachim Wagner ${ }^{1}$
}

\begin{abstract}
This empirical paper documents the relationship between the composition of a firm's workforce (with a special focus on age and gender) and its performance (productivity and profitability) for a large representative sample of enterprises from manufacturing industries in Germany using newly available, unique data. We find concave age-productivity profiles and a negative correlation of age on firms' profitability. Moreover, our micro-econometric analysis reveals for the first time that the ceteris paribus lower level of productivity in firms with a higher share of female employees does not go hand in hand with a lower level of profitability in these firms.
\end{abstract}

KEY WORDS: $\quad$ ageing; firm performance; gender; productivity; profitability; Germany

JEL Classification: D22, D24, J21, J24, L25

${ }^{1}$ Leuphana University Lueneburg, Institute of Economics, and IZA, Bonn, Germany

\section{Introduction}

Economic research has a long tradition of explaining differences in firm performance (e.g., Bartelsman \& Doms 2000; Syverson, 2011). Whereas some studies are interested in the effects of work practices (e.g., codetermination, training, incentive schemes) on firm performance, others are more interested in the relationship between the demographic structure of the workforce and firm performance. The latter stream of literature has received increasing attention due to persistent inequalities in the labor market (e.g., wage differentials between men and women, employment problems of older workers), increasing female employ-

$\underline{\square}$

Correspondence concerning this article should be addressed to: Joachim Wagner, Leuphana University Lueneburg, P.O. Box 2440 D-21314 Lueneburg, Germany.E-mail:wagner@leuphana.de ment rates, and the demographic change leading to an ageing workforce. To understand such inequality issues and to learn about potential aggregated productivity (welfare) changes in ageing societies with increasing female employment, micro-econometric studies on the effects of the age and gender composition of firms' workforces are important.

In the last two decades, several new databases have been made available to researchers. These databases include establishment and linked employer employee datasets. These new data sources are usually large representative panel datasets obtained by surveys or official statistics and which allow the application of advanced econometric techniques to the analysis of firm performance. In Germany, the most used datasets in this context are the IAB Establishment Panel (Fischer et al., 2009) and the linked employer employee data of the IAB (LIAB) (Alda, 
Bender, \& Gartner, 2005), which combines the survey data of the IAB Establishment Panel with process produced employee data of the social security agencies. A disadvantage of such voluntary survey information is that information about firms' productivity, costs, profits, and other variables are often seen as confidential by firms and might include measurement errors that can distort the empirical link between explanatory variables and outcomes. In this paper, we use a new type of data (KombiFiD project) for German enterprises from the manufacturing sector that combines official statistics of employees covered by social security and information from mandatory enterprise level surveys performed by the German Statistical Offices. Therefore, we have more reliable information than most previous studies. Moreover, we can compute firms' rates of profit, yielding new insights into the firm performance literature, as previous studies have primarily focused on productivity.

A table in the appendix presents a review of recent econometric studies that explicitly address the effects of age and gender on firm performance. All reviewed studies have in common that they use linked employer-employee data to study the productivity effects of age and gender. The used datasets are from different countries (Germany, Netherlands, Denmark, Finland, Belgium, Portugal, Canada, USA, Taiwan). The main findings of previous research can be summarized as follows. The age-productivity profiles are mostly positive concave or inverse u-shaped. However, the estimates differ among different methods and specifications. The employment share of women has mostly significant negative effects on firm productivity in OLS (Ordinary Least Squares) regressions and non-significant effects in GMM (General Method of Moments) regressions. Especially noteworthy are the last three papers in the appendix table by Cardoso, Guimarares, and Varejao (2011) for Portugal, van Ours and Stoeldraijer (2011) for the Netherlands, and Göbel and Zwick (2012) for Germany, as they are the most comparable to our study with respect to data, variables, specifications, and methods. Although previous research has analyzed firm productivity and the productivity-wage gap, we do not know of any study that has explicitly analyzed the effects of age and gender composition of the workforce on firms' profit- ability. ${ }^{1}$ Consequently, we present the first evidence for direct links between workforce composition and firm profits.

In our micro-econometric analysis, we use a balanced panel of 4,225 enterprises from German manufacturing for the years 2003 to 2006 and apply pooled OLS regressions, fully robust MM regressions to account for outliers, and GMM first difference regressions to account for unobserved heterogeneity and endogeneity issues. To anticipate our most important results, our analysis of this new type of German data confirms previous findings of positive concave age-productivity profiles and adds a new finding of a rather negative effect of age on firms' profitability. The finding for productivity is consistent with standard human capital considerations (amortization periods, depreciation). The finding for profit is consistent with deferred compensation considerations (underpayment of younger and overpayment of older employees). Whereas the concave age-productivity profiles do not support fears of declining productivity due to an ageing workforce and cannot explain the employment problems of older workers, the negative effect of age on firm profits highlights the employment barrier for older workers from a labor demand side. Our analysis furthermore reveals, for the first time, that the ceteris paribus lower level of productivity in firms with a higher share of female employees does not go hand in hand with a lower level of profitability in these firms. If anything, profitability is (slightly) higher in firms with a larger share of female employees. This finding might indicate that a lower productivity of women is (over)compensated by their lower labor costs, which in turn might indicate general labor market discrimination against women or lower reservation wages and less engagement in individual wage bargaining by women.

The rest of the paper is organized as follows. Section 2 describes the data used and the definitions of the variables and presents descriptive statistics. Section 3 presents and discusses the approaches for our micro-econometric investigation. Section 4 contains the results of our micro-econometric analyses. The paper concludes in Section 5 with a summary and discussion of our results as well as comments on the newly available data for enterprises from German manufacturing used for the study. 


\section{Data, definition of variables and descriptive statistics}

The empirical investigation uses data for manufacturing industry enterprises ${ }^{2}$. These data come from two sources. The first source is the cost structure survey for enterprises in the manufacturing sector. This survey is carried out annually by the statistical offices as a representative random sample survey stratified according to the number of employees and industries (see Fritsch et al., 2004). The sample covered by the cost structure survey represents all enterprises with at least 20 employees from manufacturing industries. Approximately 45 percent of the enterprises with 20 to 499 employees and all enterprises with 500 or more employees are included in the sample. ${ }^{3}$ Although firms with 500 or more employees are covered by the cost structure survey in each year, the sample of smaller firms is part of the survey for four years in a row only.

This survey is the source for information on productivity, profitability, firm size and industry affiliation:

Productivity is measured as labor productivity, defined as value added per head (in Euro and in current prices). Information on the capital stock of a firm is not available from the cost structure survey, so more elaborate measures of total factor productivity cannot be used in this study. Bartelsman and Doms (2000, p. $575)$ note that heterogeneity in labor productivity is accompanied by similar heterogeneity in total factor productivity in the reviewed research where both concepts are measured. In a recent comprehensive survey, Chad Syverson (2011) argues that high-productivity producers will tend to appear efficient regardless of the specific way their productivity is measured. ${ }^{4}$ Furthermore, Foster, Haltiwanger and Syverson (2008) show that productivity measures that use sales (i.e., quantities multiplied by prices) or quantities only are highly positively correlated. Therefore, we argue that labor productivity is a suitable measure for productivity at the firm level. Labor productivity is computed as:

\footnotetext{
value added $\left.\begin{array}{l}\text { total sales (w/o sales taxes) } \\ - \text { costs for materials (w/o sales taxes) } \\ - \text { other costs } \\ - \text { taxes (w/o sales taxes) } \\ + \text { subsidies received }\end{array}\right)(1)$
}

Profitability of a firm is computed as a rate of return, defined as gross firm surplus (computed in line with the definition of the European Commission (1998) as gross value added at factor costs minus gross wages and salaries minus costs for social insurance paid by the firm) divided by total sales (net of VAT) minus the net change of inventories: ${ }^{5}$

rate of profit $=\frac{\begin{array}{l}\text { gross value } \\ \text { added }\end{array}-\begin{array}{l}\text { gross } \\ \text { wages }\end{array}-\begin{array}{l}\text { costs for social } \\ \text { insurance }\end{array}}{\text { totalsales }- \text { net change of inventories }}$

Firm size is measured by the number of people working in a firm. This measure is also included in squares in the empirical models to address non-linearity in the relation between firm size and firm performance.

Industry affiliation of a firm is recorded at the twodigit level.

The second source of data is the Establishment History Panel (Betriebs-Historik-Panel). ${ }^{6}$ Details aside, this dataset is built from individual level information for employees covered by social security. ${ }^{7}$ In a first step, for each year from 1975 onward, information for all employees working in a local production unit (establishment) was aggregated, and this is the standard version of the Establishment History Panel. In this study, we use a different version of the Establishment History Panel. For multi-establishment enterprises, information from all establishments of the enterprise was aggregated in a second step. The result is a dataset with detailed information about the characteristics of the employees (covered by social security) in each enterprise in a year.

Information reported to the social security system includes sex, age and qualifications (educational level attained and vocational training completed).

Share of employees from a certain age group is defined as the total number of employees (covered by social security) from the respective age group over the total number of employees (covered by social security) in an enterprise; the share is measured as a percentage.

Share of female employees is defined as the total number of females (covered by social security) over the total number of employees (covered by social security) in an enterprise; the share is measured as a percentage.

Share of medium qualified employees is defined as the total number of employees (covered by social secu- 
Table 1. Descriptive statistics

\begin{tabular}{|c|c|c|c|c|}
\hline \multirow[b]{2}{*}{ Variables } & \multicolumn{4}{|c|}{ Standard deviation } \\
\hline & Mean & Overall & Between & Within \\
\hline Value added per head (Euro) & 57812.53 & 30320.34 & 27734.55 & 12257.83 \\
\hline Rate of profit (\%) & 8.12 & 9.55 & 8.28 & 4.76 \\
\hline Share of employees aged less than 30 years (\%) & 17.16 & 9.39 & 8.98 & 2.75 \\
\hline Share of employees aged 30 - 49 years (\%) & 57.57 & 9.33 & 8.72 & 3.32 \\
\hline Share of employees aged 50 years or older (\%) & 25.25 & 10.10 & 9.66 & 2.94 \\
\hline Share of employees aged 15 - 19 years (\%) & 3.10 & 3.92 & 3.60 & 1.55 \\
\hline Share of employees aged 20 - 24 years (\%) & 6.46 & 4.59 & 4.13 & 2.01 \\
\hline Share of employees aged $25-29$ years (\%) & 7.60 & 4.58 & 4.11 & 2.02 \\
\hline Share of employees aged 30 - 34 years (\%) & 10.84 & 5.05 & 4.30 & 2.64 \\
\hline Share of employees aged 35 - 39 years (\%) & 16.00 & 5.43 & 4.63 & 2.84 \\
\hline Share of employees aged 40 - 44 years (\%) & 16.72 & 5.18 & 4.36 & 2.80 \\
\hline Share of employees aged 45 - 49 years (\%) & 14.01 & 5.11 & 4.42 & 2.56 \\
\hline Share of employees aged 50 - 54 years (\%) & 11.44 & 5.04 & 4.47 & 2.31 \\
\hline Share of employees aged 55 - 59 years (\%) & 8.20 & 4.80 & 4.28 & 2.18 \\
\hline Share of employees aged 60 - 64 years (\%) & 4.06 & 3.59 & 3.04 & 1.92 \\
\hline Share of employees aged 65 years or older (\%) & 1.55 & 2.79 & 2.55 & 1.13 \\
\hline Share of female employees (\%) & 30.12 & 20.76 & 20.63 & 2.38 \\
\hline Share of medium qualified employees (\%) & 61.52 & 20.54 & 20.24 & 3.47 \\
\hline Share of highly qualified employees (\%) & 6.03 & 7.85 & 7.70 & 1.50 \\
\hline Share of part-time employees (\%) & 18.18 & 14.60 & 14.23 & 3.27 \\
\hline Firm size (number of employees) & 429.68 & 3649.52 & 3644.74 & 192.87 \\
\hline
\end{tabular}

Note: The data are from a balanced panel (4 years, from 2003 to 2006) with a total of 16,900 yearly observations for 4,225 enterprises. For the definitions of the variables, see text.

rity) with either a high-school diploma (Abitur) as the highest educational level attained or with vocational training completed over the total number of employees (covered by social security) in an enterprise; the share is measured as a percentage.

Share of highly qualified employees is defined as the total number of employees with a polytech or university degree over the total number of employees (covered by social security) in an enterprise; the share is measured as a percentage. ${ }^{8}$

Share of part-time employees is defined as the total number of part-time employees over the total number of employees (covered by social security) in an enterprise; the share is measured as a percentage.
The cost structure survey for enterprises in the manufacturing sector is conducted by the German statistical offices. The data can be accessed for scientific research via the Research Data Centres of the Federal Statistical Office and the Statistical Offices of the Federal States (see Zühlke et al., 2004). The Establishment History Panel is built from administrative data by the Research Data Centre of the Federal Employment Agency at the Institute for Employment Research. The data can be accessed via the Research Data Centre for scientific research (see Spengler 2008).

Linking this confidential firm level information across the borders of the data producers, however, is difficult. Details aside, this is technically challenging 
(though not impossible) and is legal only if the firm agrees in writing. The basic idea of the KombiFiD (an acronym that stands for Kombinierte Firmendaten für Deutschland, or combined firm level data for Germany) project, described in detail on the web (see www. kombifid.de), is to ask a large sample of firms from all parts of the German economy to agree to match confidential micro data for these firms. These data are kept separately by three data producers (the Statistical Offices, the Federal Employment Agency, and the German Central Bank) in one dataset. These matched data are made available for scientific research while strictly obeying the data protection law, i.e., without revealing micro level information to researchers outside the data producing agencies. In KombiFiD, 54,960 firms were asked to agree in writing to merge firm level data from various surveys and administrative data for the reporting years 2003 to 2006. A total of 30,944 firms replied, and 16,571 agreed. These 16,571 firms are in the KombiFiD Agreement Sample. ${ }^{9}$

The sample of enterprises used in the empirical investigation performed here consists of all firms from manufacturing industries in West Germany ${ }^{10}$ in the KombiFiD Agreement Sample for which information from both data sources - the cost structure survey and the Establishment History Panel - could be linked in the KombiFiD project. Enterprises that do not have complete information for each year from 2003 to 2006 were dropped from the computations. ${ }^{11}$ This leads to a balanced panel dataset with 16,900 observations for 4,225 firms and 4 years.

Descriptive statistics for all variables and the pooled data are reported in Table 1. It is evident from these descriptive statistics that the variation of the share of females and of the share of employees in the two qualification groups are small over the four years covered compared with the variation between the firms in the sample. The same holds for the variation in firm size. Therefore, the within firm variation of important dimensions of diversity of the employees over time cannot be used in fixed effects models to sufficiently identify any relationship between changes in firm performance over time and the diversity of employees.

Furthermore, a comparison of the mean and the standard deviation of the variables indicate that some firms may have characteristics that differ by orders of magnitude from the rest of the firms in the sample.
Unfortunately, due to strict data protection rules it is not possible to report the minimum and maximum values of the variables in Table 1 (because these are figures for a single firm that may not be revealed). This is less of a problem for all the variables that are defined as shares because their values are bound between zero and one hundred percent by definition. However, for value added per head, the rate of profit and firm size, we know from (unpublished) results of investigations of the KombiFiD Agreement Sample that there are extremely low or high values of these variables for some firms. These extreme observations, or outliers, may be highly influential in any empirical investigation. This aspect of the data, therefore, should be addressed.

\section{Approaches for the micro- econometric investigation}

The investigation of the link between the diversity of employees (especially the composition of the workforce by age and gender) and two dimensions of firm performance (productivity measured as value added per head in Euros and profitability measured as the rate of profit in percent) ${ }^{12}$ uses empirical models that regress the performance variable on the shares of employees from different age groups, the share of female employees ${ }^{13}$, the shares of highly and medium qualified employees ${ }^{14}$, the share of part-time employees, and the firm size (number of employees), which is also included in squares to address a non-linear relationship, a set of dummy variables for years and industries, and a constant. We consider two variants of this empirical model. Model 1 includes two variables for the share of employees aged 30 to 49 years and for the share of employees aged 50 years or older (taking the group of employees who are less than 30 years old as the reference group). Model 2 includes ten variables for the shares of employees aged 15 - 19 years, 20 - 24 years, 25 - 30 years, etc., up to the share of employees aged 65 or older. ${ }^{15}$ We decided to include the group 65 or older separately to account for potential anomalies (e.g., motivation, remaining paid holidays) in the last year before retirement and the few employees working beyond the legal retirement age of 65 years.

Note that these regression equations are not meant to be an empirical model to explain labor productivity or profitability at the enterprise level; the dataset here is not rich enough for such an exercise. These equa- 
tions are simply a vehicle to test for and estimate the size of the relation between firm performance and one dimension of workforce diversity controlling for other firm characteristics. Furthermore, note that productivity differences at the firm level are notoriously difficult to explain empirically. "At the micro level, productivity remains very much a measure of our ignorance" (Bartelsman \& Doms 2000, p. 586). Syverson (2011) surveys the recent literature on determinants of productivity at the firm level. Inter alia, he mentions effects of competition, organizational structures within firms, payment systems, other human resources practices, managerial talent, human capital, higher-quality capital inputs, information technology (IT) and R\&D. All these determinants of productivity are important for profitability as well, and they cannot be examined here with the data at hand. These limitations should be kept in mind when putting the results in perspective.

In a first step, the empirical models were estimated for the pooled data from 2003 to 2006 by Ordinary Least Squares (OLS). The descriptive statistics presented above revealed that the variation of the share of females and of employees in the two large qualification groups are small over the four years covered compared with the variation between the firms in the sample. The same holds for the variation of firm size. Therefore, the within firm variation of important dimensions of diversity of the employees over time cannot be used to identify any relationship between changes in firm performance over time and the diversity of employees by adding fixed firm effects. To address the dependence of the error term between observations from one firm over the four years, the standard errors of the estimated regression coefficients are clustered at the firm level. ${ }^{16}$

In a second step, we address the problem that some firms have values for some variables (value added per head, the rate of profit and firm size) that are extremely low or high compared with the other firms in the sample (as mentioned in the discussion of the descriptive statistics for the data used here). This problem often occurs when one investigates a sample of heterogeneous firms. These extreme values may be the result of reporting errors (and, therefore, are wrong) or may be due to idiosyncratic events or firm behavior that is vastly different from the behavior of the majority of firms in the sample.
Observations of this type are termed outliers. Whatever the reason may be, extreme values of productivity or profitability may have a large influence on the mean value of the performance variable and on the estimates of the coefficients that show the link between firm performance and a dimension of diversity of the workforce. The conclusions, therefore, may be influenced by a small number of firms with extremely high or low values of productivity or profitability.

Researchers from the field of micro-econometrics of firm activities are usually aware of all these problems. Given that, due to the confidentiality of the firm level data, single observations as a rule cannot be inspected closely enough to detect and correct reporting errors or to understand the idiosyncratic events that lead to extreme values, a widely used procedure to keep these extreme observations from shaping the results is to drop the observations from the top and bottom one percent of the distribution of the variable under investigation. A case in point is the international comparison study on the exporter productivity premium by the International Study Group on Exports and Productivity (2008, p. 610).

Dropping the firms from the top and bottom one percent of the productivity distribution and comparing the results of empirical investigations with and without these firms with extremely high or extremely low values of labor productivity might be considered as a first and useful step to check the sensitivity of the results. However, although this approach seems to be rather popular, it is in some sense arbitrary. Why the top and bottom one percent? Why not choose a larger or smaller cut-off point?

There are alternative approaches to address extreme observations (outliers) that are substantiated in statistics. One approach advocated in the literature is quantile regression. As Yasar, Nelson and Rejesus (2006, p. 682) state: "Quantile regression estimates are considered robust relative to least squares estimates. In contrast to the least squares estimator, the quantile regression estimates place less weight on outliers and are found to be robust to departures from normality." Quantile regression at the median is identical to least absolute deviation (LAD) regression, which minimizes the sum of the absolute values of the residuals rather than the sum of their squares (as in OLS). This estimator is also known as the $\mathrm{L}_{1}$, or median regression, 
estimator. LAD regression, however, is not a panacea against outliers. To see why, following Rousseeuw and Leroy (1987) we distinguish three types of outliers that influence the OLS estimator: vertical outliers, bad leverage points, and good leverage points. Verardi and Croux (2009, p. 440) illustrate this terminology in a simple linear regression framework (the generalization to higher dimensions is straightforward) as follows: "Vertical outliers are those observations that have outlying values for the corresponding error term (the $y$ dimension) but are not outlying in the space of explanatory variables (the $x$ dimension). Their presence affects the OLS estimation and, in particular, the estimated intercept. Good leverage points are observations that are outlying in the space of explanatory variables but that are located close to the regression line. Their presence does not affect the OLS estimation, but it affects statistical inference because they do deflate the estimated standard errors. Finally, bad leverage points are observations that are both outlying in the space of explanatory variables and located far from the true regression line. Their presence significantly affects the OLS estimation of both the intercept and the slope."

Using this terminology, one can state that the median regression estimator protects against vertical outliers but not against bad leverage points (Koenker 2005, p. 268; Verardi \& Croux 2009, p. 441). Full robustness can be achieved by using the so-called MM-estimator which can resist contamination of the dataset of up to 50 percent of outliers (i.e., it has a breakdown point ${ }^{17}$ of 50 percent compared with zero percent for OLS). A discussion of the details of this estimator is beyond the scope of this paper (see Verardi \& Croux, (2009) for this estimator and for Stata commands to compute it). Suffice it to say that this estimator combines a breakdown point of 50 percent with a high efficiency (the degree of which can be chosen by the researcher). An explicit formula for the estimator is not available; it is computed by numerical optimization.

Given that the presence of outliers can be expected to be the rule in datasets for heterogeneous firms, it is important to document the extent to which estimation results are influenced by extreme observations. Therefore, the two empirical models for productivity and profitability are estimated using the fully robust MM-estimator as well. ${ }^{18}$
In a third step, we estimate GMM (General Method of Moments) first difference regressions (see Roodman, (2009) for this estimator and for Stata commands to compute it). Due to the short panel and low within variance of most explanatory variables, our GMM estimates serve only as a robustness check, and we expect imprecise estimates with large standard errors. Nevertheless, it is important to check for potential endogeneity issues, as our previous estimates might only be interpreted as descriptive evidence for between firm differences that need not represent causal effects.

The first source of endogeneity might stem from an omitted variable bias. To address this problem, differences are first used to cancel out unobserved time invariant firm heterogeneity. The second source of endogeneity is reverse causality, as short-term productivity shocks should affect workers' in- and out-flows differently across demographic groups, consequently affecting the composition of the workforce. For example, a negative shock is likely to lead to relatively more layoffs of younger than older workers (e.g., due to employment protection legislation or internal labor markets) and a positive shock to the recruitment of relatively more younger than older workers. Therefore, employment shares of older workers could be negatively correlated with productivity shocks, which would lead to a downward bias in OLS if endogeneity is not properly taken into account. The same logic might be applicable to the gender composition. If men have, on average, a lower layoff probability than women (e.g., due, on average, to longer tenure, more investments in human capital, being the main contributor to household income, or tastebased and statistical discrimination), the employment share of women could be positively correlated with productivity shocks, which would lead to an upward bias in OLS. However, if firms reduce female employment in case of negative shocks, the still employed women are likely to be a positive selection, i.e., they should, on average, be more productive than the laid off women and might even be more productive than their male counterparts. From this follows a downward bias if endogeneity is not properly taken into account. Thus, two opposing effects can bias estimates of female employment on firm performance. To address this type of endogeneity, we follow the standard approach in the literature where the first differences are instrumented with the second and third lags of their own levels. 
Table 2. Estimates for productivity

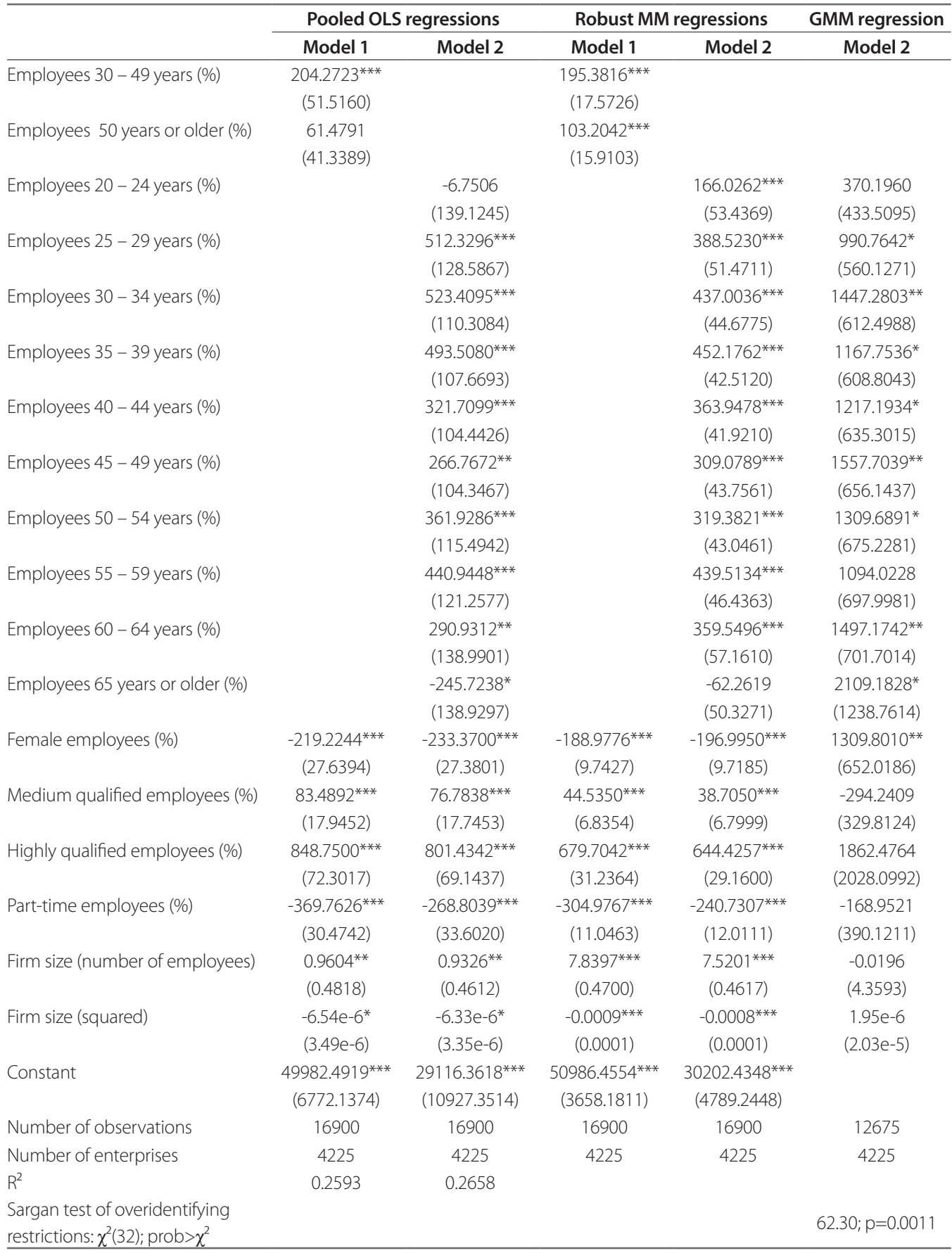

Note: The dependent variable is value added per head (Euro). All models include dummy variables for years and 2-digit-level industries. Standard errors clustered at the firm level are in parentheses for OLS and MM regressions. Two-step GMM first difference regressions for model 2; first differences are instrumented with second and third lags of their own levels. Robust standard errors are in parentheses for GMM regressions. Coefficients are significant at ${ }^{*} p<0.10,{ }^{* *} p<0.05$, and ${ }^{* *} p<0.01$. 



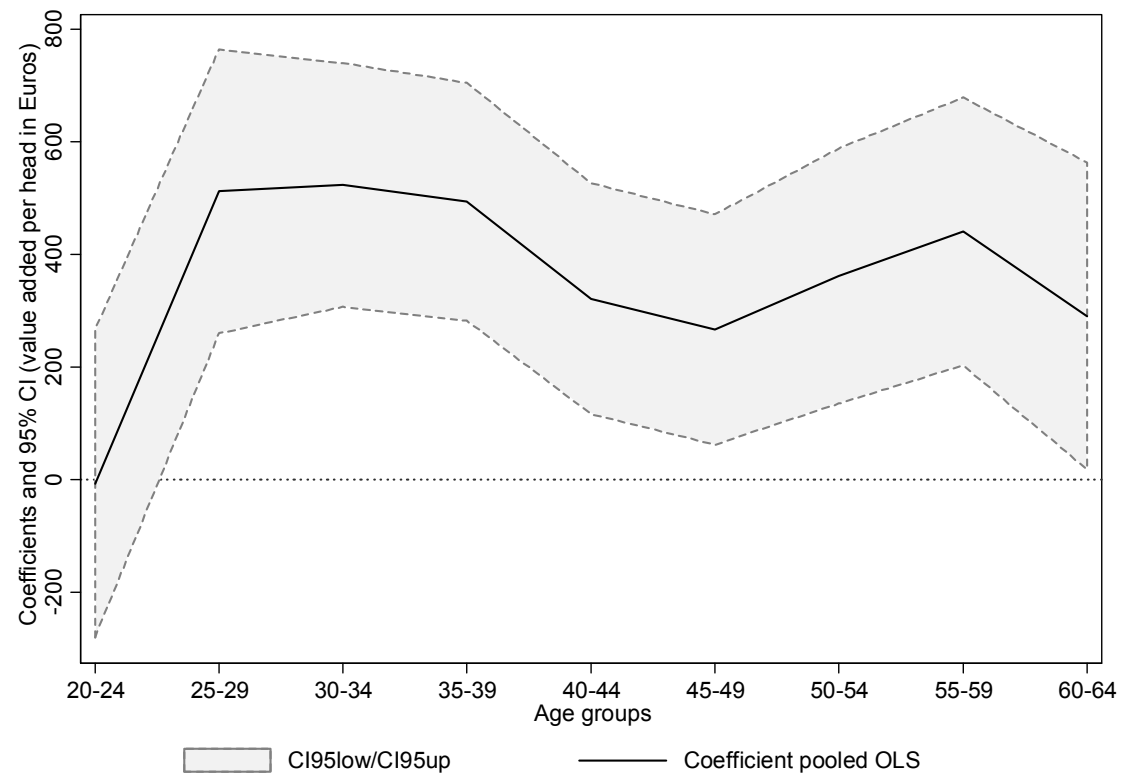

Figure 1. Age-productivity profiles (model 2) for pooled OLS regression

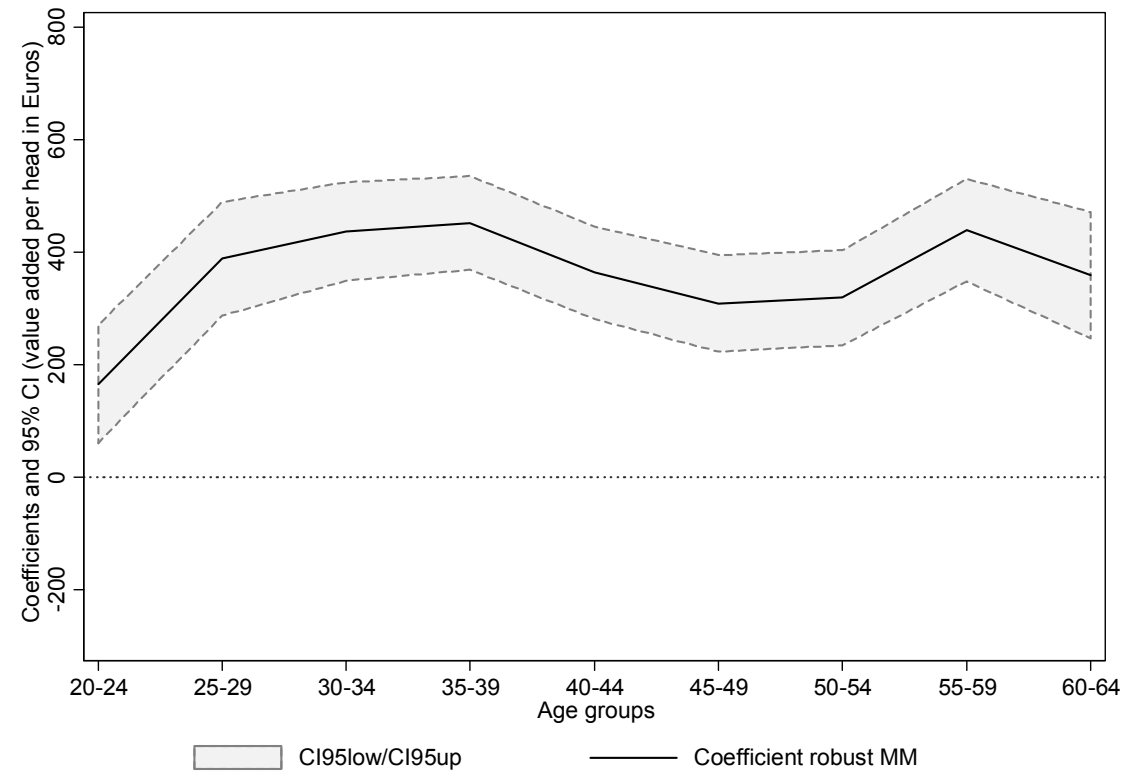

Figure 1. Age-productivity profiles (model 2) for robust MM regression 


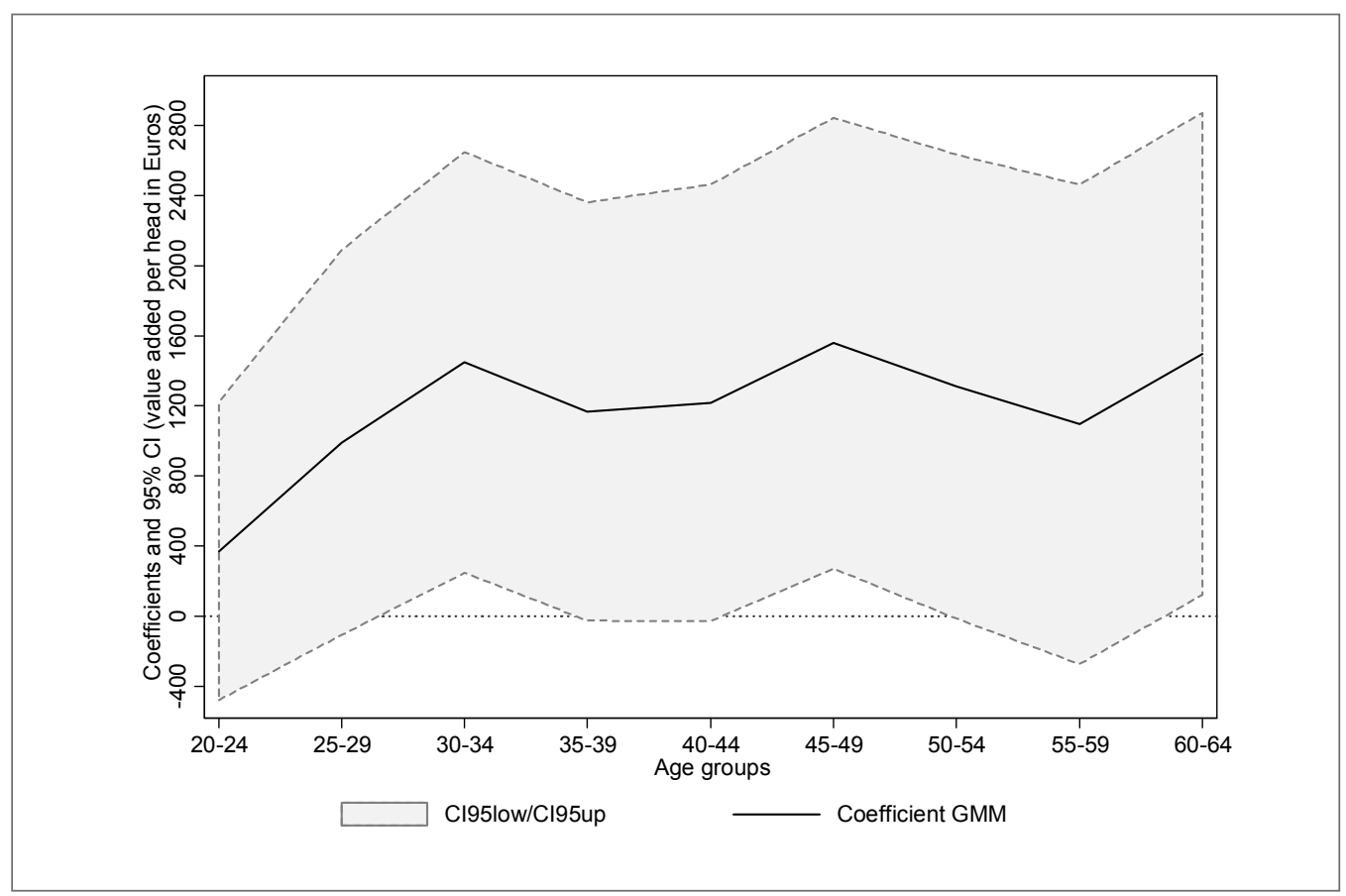

Figure 3. Age-productivity profile (model 2) for GMM regression

Model 2 as robustness checks, whose results for productivity are presented in the last column of Table 2. As expected, the estimated parameters are imprecise (and large) and have large standard errors, which is likely to occur because we can only analyze the differences between 2006 and 2005 due to our four year panel. Hence, we stress again that the results of our GMM regressions should not be overemphasized and serve only as a robustness check. In the GMM productivity regressions, only the female share and the employment shares of age groups have significant effects. Compared with our previous results, the female share has now turned from a significant negative to a significant positive effect on productivity. Although we can only speculate, this finding could indicate a downward bias in pooled OLS and robust MM regressions that is driven by a positive selection of the remaining women in the case of negative productivity shocks. Figure 3 plots the age-productivity profile, which is again positive concave and supports our previous findings from the pooled OLS and robust MM regressions.
Table 3 presents our main empirical results for the links between workforce composition and firm profitability (rate of profit in percent) for pooled OLS and robust $\mathrm{MM}$ regressions. Note that the explained variance of profits is rather low $\left(\mathrm{R}^{2}=0.041\right.$ for Model $1, \mathrm{R}^{2}=0.047$ for Model 2), which indicates that firm profits are more influenced by random shocks than is firm productivity. The descriptive statistics (see Table 1 in Section 2) also reveal that the coefficient of variation for the rate of profit $(\mathrm{CV}=9.55 / 8.12=1.18)$ is substantially larger than for the value added per head $(\mathrm{CV}=30320.34 / 57812.53=0.52)$. Our empirical models are not meant to identify business strategies to increase profitability but to analyze whether firms with different workforce compositions differ in their profitability. In fact, the overall low explanatory power of our models strengthens the few significant findings, even if they are rather small from a quantitative perspective. Again, we will discuss the results for Model 1 first before we discuss the age-profit profiles obtained for Model 2. 
Table 3. Estimates for profitability

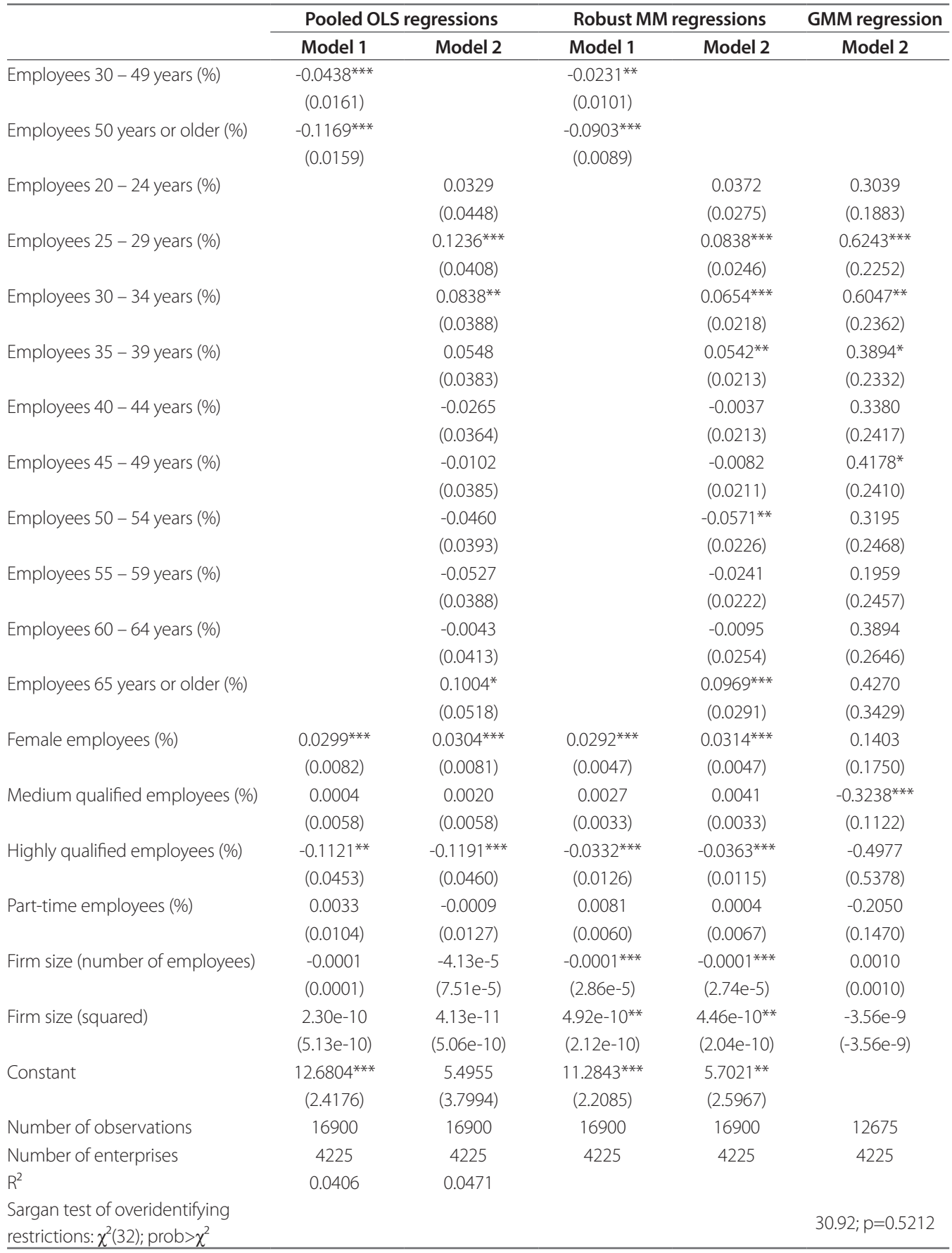

Note: The dependent variable is rate of profit (\%). All models include dummy variables for years and 2-digit-level industries. Standard errors clustered at the firm level are in parentheses for OLS and MM regressions. Two-step GMM first difference regressions for model 2; first differences are instrumented with second and third lags of their own levels. Robust standard errors are in parentheses for GMM regressions. Coefficients are significant at ${ }^{*} p<0.10,{ }^{* *} p<0.05$, and ${ }^{* * *} p<0.01$. 


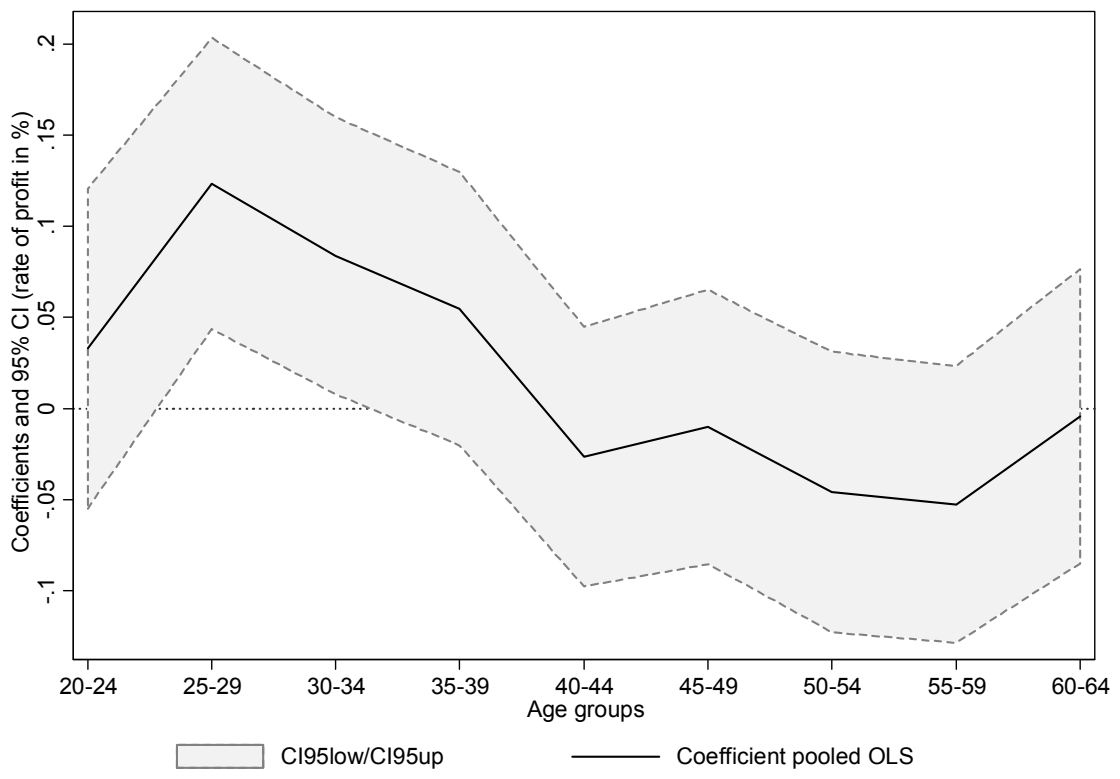

Figure 4. Age-profit profile (model 2) for pooled OLS regression

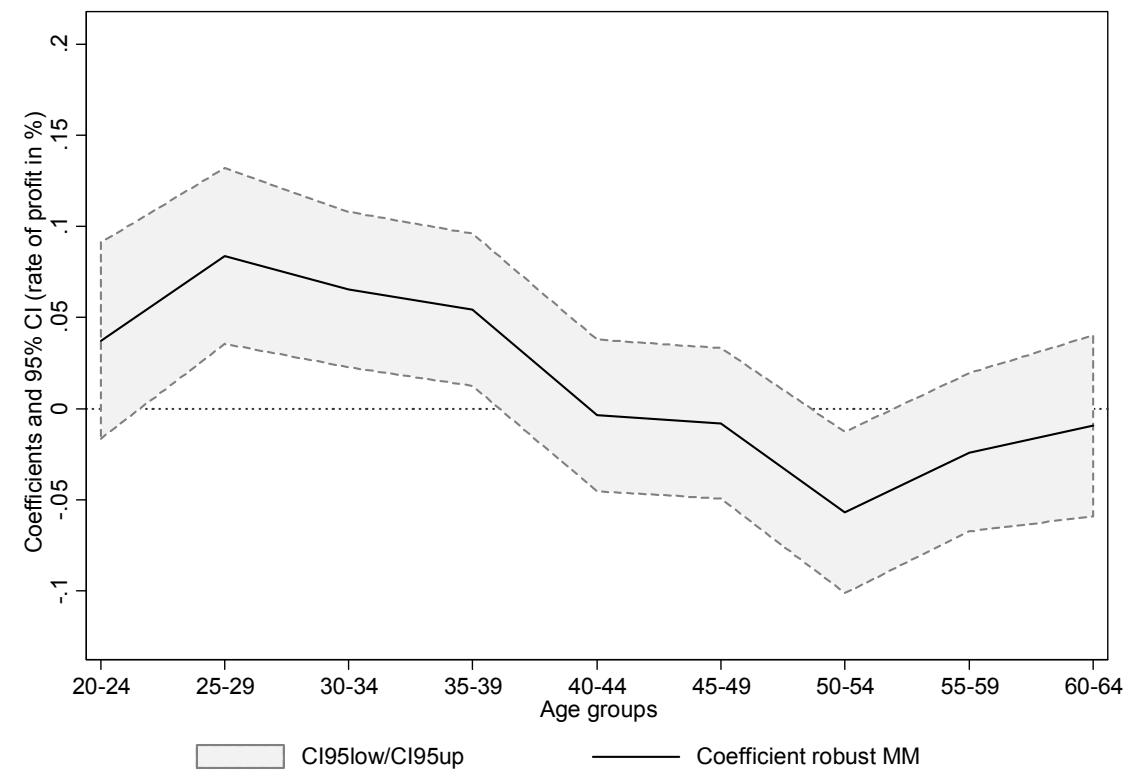

Figure 5. Age-profit profile (model 2) for robust MM regression 


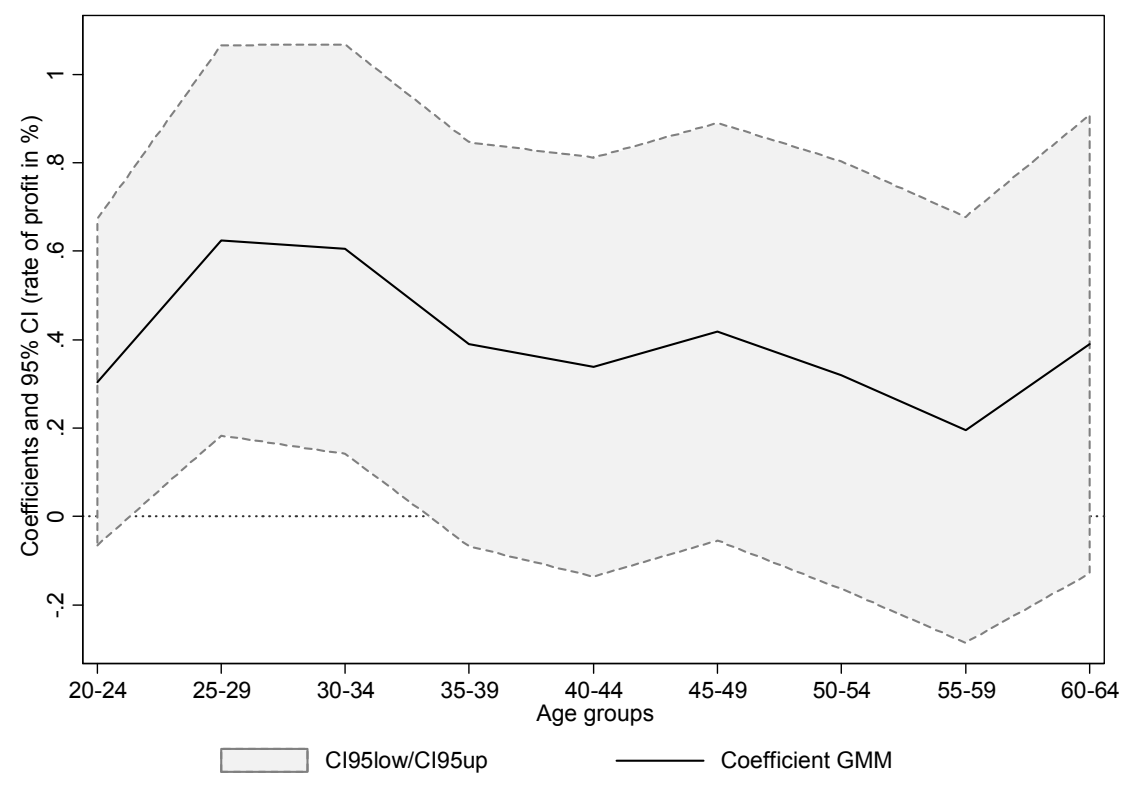

Figure 6. Age-profit profile (model 2) for GMM regression

The OLS results for Model 1 in Table 3 indicate a negative correlation of age and the rate of profit. Compared with the reference group of young employees, a one percentage point increase in the share of employees aged 30 to 49 years decreases the rate of profit by approximately 0.044 percentage points. ${ }^{19}$ The share of workers aged 50 years or older even has a negative impact of 0.117 percentage points. The share of female employees is positively correlated with profitability. A one percentage point increase in female employment is correlated with a 0.03 percentage point higher rate of profit. For our further employment structure variables, no significant coefficients were estimated except for a surprisingly negative coefficient of highly qualified employees with college degrees. The estimated coefficients and standard errors are again smaller in the robust MM than in the OLS regressions, but the changes in the main findings are not noteworthy. The estimates for Model 2 also do not show noteworthy differences. Model 2, however, allows a more precise look at the age-profit profiles, which are plotted in Figure 4 for the OLS regressions and in Figure 5 for the robust MM regressions. It can be seen that profitability increases until age 30, as was the case for productivity, and decreases afterward compared with the rather flat productivity profiles.

The results of the GMM regression for profitability are presented in the last column of Table 3. As was the case for productivity, the estimated coefficients and standard errors are larger than in the pooled OLS and robust MM regressions. The estimates reveal positive coefficients for some age groups and for the female employment share, although it is not significant. The ageprofit profile in Figure 6 shows an increase until age 30 and a slight decline afterward, although the differences between age groups are not statistically significant. Despite low statistical significance, the overall GMM results support our previous findings from the pooled OLS and robust MM regressions.

\section{Discussion and concluding remarks}

We start our discussion with a short summary of our basic findings about age and gender effects on firm performance. In line with previous research, we find 
concave age-productivity profiles that increase until age 30 and are flat afterward. The age-profit profiles indicate an increase until age 30 and a decline afterward. The employment shares of women and productivity are significantly negatively correlated in our pooled OLS and robust MM regressions but are significantly positively correlated in the GMM regressions. Profitability seems to be positively correlated with the share of female employees in all our regressions, although not significantly in the GMM regressions. Overall, most of our findings on firm productivity are in line with findings from previous research, which has been summarized in the appendix table, and we have provided new findings on firm profitability.

Our finding for age and productivity is consistent with standard human capital considerations. Human capital theory (Mincer, 1974) implies that incentives to invest in human capital decrease with age as the amortization period decreases. Moreover, human capital is usually subject to depreciation. Both arguments lead to concave or even inverse u-shaped age-productivity profiles. Our finding for age and profit is consistent with deferred compensation considerations (Lazear, 1979). In deferred compensation models with longterm employment contracts, younger workers are paid below their marginal product and older workers are paid above their marginal product to provide work incentives. Consequently, firms' short term profits are positively affected by younger workers with short tenure, who pay loans to the firm, and negatively by older workers with long tenure, who receive the repayments of their loans. Although we cannot explicitly analyze tenure effects due to missing information in the data, age can be interpreted in this context because the German manufacturing sector is characterized by stable employment, making age and tenure quite collinear. Moreover, seniority arrangements with respect to age are usually part of collective contracts, which are binding to most firms in the German manufacturing sector. Whereas the concave age-productivity profiles cannot explain the employment problems of older workers, the negative effect of older workers on profits highlights the employment barrier for older workers from a labor demand side that might be explained by deferred compensation schemes (Heywood, Jirjahn, \& Tsertsvardze, 2010; Hutchens, 1986). A similar conclusion can be drawn from previous studies that analyze the productivity-wage gap (e.g., Cardoso et al., 2011; Cataldi, Kampelmann, \& Rycx, 2011; van Ours \& Stoeldraijer, 2011). Moreover, our findings are important in that they do not support the fear of declining productivities in ageing societies.

Although our findings for gender and productivity are unclear from a causal perspective, we were able to document that firms with higher shares of female employees do not have lower levels of profitability. If anything, profitability is (slightly) higher in firms with a larger share of female employees. This finding might indicate that the often reported lower productivity of women is (over)compensated by lower labor costs for women, which in turn might indicate general labor market discrimination against women. The related rationale based on taste-based discrimination (Becker, 1988) would be that owners need to be compensated with higher profits if they employ women whom they dislike because of their gender. This discrimination argument is in principal valid for all employees with profit sharing schemes and not only for owners, who are unlikely to have personal contact with employees in larger firms. Another rationale based on labor supply considerations is that women are willing to accept lower wages due to lower reservation wages (Humpert \& Pfeifer, 2013) and less engagement in individual wage bargaining (Babcock \& Laschever 2003).

Based on our results, we can speculate about the effects of affirmative action policies, which are unlikely to be clear-cut. Enforced increases of female employment via legal employment quotas may have the perverse effect of increasing profits for capital owners and of decreasing the productivity in an economy, which is likely to reduce welfare due to lower wages and higher prices. Equal pay legislation might lead to the adverse effect of reducing female employment if owners or other employees with profit sharing insist on compensation for their utility loss from distaste. However, if firms' profits are only larger due to an underpayment of women caused by lower reservation wages and fewer wage bargaining activities, equal pay legislation might not have adverse effects on female employment but will negatively impact firms' profits. Overall, a combination of female quotas and equal pay legislation might be necessary to effectively improve the employment situation of women and to reduce gender wage gaps. Whether such a policy would be ef- 
ficient, however, is questionable and requires further research (e.g., natural experiments). Moreover, new gender inequalities and injustices in the labor market might arise that favor young women and disadvantage young men.

\section{References}

Alda, H., Bender, S., \& Gartner, H. (2005). European Data Watch: The linked employer-employee dataset created from the IAB establishment panel and the process-produced data of the IAB (LIAB). Journal of Applied Social Science Studies, 125 (2), 327-336.

Babcock, L., \& Laschever, S. (2003). Women don't ask: negotiation and the gender divide. Princeton, NJ: Princeton University Press.

Bartelsman, E. J., \& Doms, M. (2000). Understanding Productivity: Lessons from Longitudinal Micro Data. Journal of Economic Literature, 38 (3), 569-594.

Becker, G. S. (1988). The economics of discrimination (10 ${ }^{\text {th }}$ ed.). Chicago, IL: University of Chicago Press.

Cardoso, A. R., Guimarares, P., \& Varejao, J. (2011). Are older workers worthy of their pay? An empirical investigation of age-productivity and age-wage nexuses. De Economist, 159 (2), 95-111.

Cataldi, A., Kampelmann, S., \& Rycx, F. (2011). Productivity-wage gaps among age groups: does the ICT environment matter? De Economist, 159 (2), 193-221.

Dostie, B. (2011). Wages, productivity and aging. De Economist, 159 (2), 139-158.

European Commission (1998). Commission Regulation (EC) No. 2700/98 concerning the definitions of characteristics for structural business statistics, Brussels. Official Journal of the European Communities L344, 18/12/1998, 49-80.

Fischer, G., Janik, F., Müller, D., \& Schmucker, A. (2009). European Data Watch: The IAB Establishment Panel - things users should know. Schmollers Jahrbuch - Journal of Applied Social Science Studies, 129 (1), 133-148.

Foster, L., Haltiwanger, J., \& Syverson, C. (2008). Reallocation, Firm Turnover, and Efficiency: Selection on Productivity or Profitability? American Economic Review, 98 (1), 394-425.

Fritsch, M., Görzig, B., Hennchen, O., \& Stephan, A. (2004). European Data Watch: Cost Structure Surveys for Germany. Schmollers Jahrbuch - Journal of Applied Social Science Studies, 124 (4), 557-566.
Göbel, C., \& Zwick, T. (2012). Age and productivity: sector differences. De Economist, 160 (1), 35-57.

Grund, C., \& Westergaard-Nielsen, N. (2008). Age structure of the workforce and firm performance. International Journal of Manpower, 29 (5), 410-422.

Haltiwanger, J. C., Lange, J. I., \& Spletzer, J. R. (1999). Productivity differences across employers: the roles of employer size, age and human capital. American Economic Review, 89 (2), 94-98.

Hethey-Maier, T., \& Seth, S. (2010). Das Betriebs-Historik-Panel (BHP) 1975 - 2008. Handbuch Version 1.0.2. Forschungsdatenzentrum der Bundesagentur für Arbeit im Institut für Arbeitsmarkt- und Berufsforschung, FDZ-Datenreport 04/2010. [The IAB Establishment History Panel 1975 - 2008. Handbook Version 1.0.2. Research Data Centre of the Federal Employment Agency at the Institute for Employment Research, FDZ Datenreport Series 04/2010EN]. Nuremberg. Retrieved from http:// doku.iab.de/fdz/reporte/2010/DR_04-10.pdf

Heywood, J. S., Jirjahn, U., \& Tsertsvardze, G. (2010). Hiring older workers and employing older workers: German evidence. Journal of Population Economics, 23 (2), 595-615.

Humpert, S., \& Pfeifer, C. (2013). Explaining age and gender differences in employment rates: a labor supply side perspective. Journal of Labor Market Research, 46 (1), 1-17

Hutchens, R. M. (1986). Delayed payment contracts and a firm's propensity to hire older workers. Journal of Labor Economics, 4 (4), 439-457.

Ilmakunnas, P., \& Ilmakunnas, S. (2011). Diversity at the workplace: whom does it benefit? De Economist, 159 (2), 223-255.

International Study Group on Exports and Productivity. (2008). Understanding Cross-Country Differences in Exporter Premia: Comparable Evidence for 14 Countries. Review of World Economics 144 (4), 596-635.

Koenker, R. (2005). Quantile Regression. Cambridge, UK: Cambridge University Press.

Lallemand, T., \& Rycx, F. (2009). Are older workers harmful for firm productivity? De Economist, 157 (3), 273-292.

Lallemand, T., Plasman, R., \& Rycx, F. (2003). Intrafirm wage dispersion and firm performance: a review and empirical tests of Belgian data. Brussels Economic Review, 46 (4), 5-29. 
Lazear, E. P. (1979). Why is there mandatory retirement? Journal of Political Economy, 87 (6), 1261-1284.

Liu, J. T., Tsou, M. W., \& Wang, P. (2010). Workforce composition and firm productivity: evidence from Taiwan. Economic Inquiry, 48 (4), 1032-1047.

Mincer, J. (1974). Schooling, experience, and earnings. New York, NY: National Bureau of Economic Research.

Parrotta, P., Pozzoli, D., \& Pytlikova, M. (2010), Does labor diversity affect firm productivity? (Working Paper No. 10-12). Aarhus School of Business, Department of Economics.

Roodman, D. (2009). How to do xtabond2: an introduction to difference and system GMM in Stata. The Stata Journal, 9 (1), 86-136.

Rousseeuw, P. J., \& Leroy, A. M. (1987). Robust Regression and Outlier Detection. New York, NY: John Wiley and Sons.

Spengler, A. (2008). The European Data Watch: The Establishment History Panel. Schmollers Jahrbuch -Journal of Applied Social Science Studies, 128 (3), 501-509.

Syverson, C. (2011). What determines productivity? Journal of Economic Literature, 49 (2), 326-365.

van Ours, J. C., \& Stoeldraijer, L. (2011). Age, wage and productivity in Dutch manufacturing. De Economist, 159 (2), 113-137.

Vandenberghe, V. (2011a). Boosting the employment rate of older men and women: an empirical assessment using Belgian firm-level data on productivity and labour costs. De Economist, 159 (2), 159-191.

Vandenberghe, V. (2011b). Firm-level evidence on gender wage discrimination in the Belgian private economy. LABOUR, 25 (3), 330-349.

Verardi, V., \& Croux, C. (2009). Robust regression in Stata. The Stata Journal, 9 (3), 439-453.

Wagner, J. (2012). The Quality of the KombiFiD-Sample of Enterprises from Manufacturing Industries: Evidence from a Replication Study. Schmollers Jahrbuch - Journal of Applied Social Science Studies, 132 (3), 379-392.

Yasar, M., Nelson, C. H., \& Rejesus, R. (2006). Productivity and Exporting Status of Manufacturing Firms: Evidence from Quantile Regressions. Review of World Economics, 142 (4), 675-694.
Zühlke, S., Zwick, M., Scharnhorst, S., \& Wende, T. (2004). European Data Watch: The research data centres of the Federal Statistical Office and the statistical offices of the Länder. Schmollers JahrbuchJournal of Applied Social Science Studies, 124 (4), 567-578. 
Appendix: Review of recent econometric studies on the effects of age and gender on firm performance

\begin{tabular}{|c|c|c|c|c|c|}
\hline Study & Country, years, data & Estimation methods & $\begin{array}{l}\text { Firm performance } \\
\text { indicators }\end{array}$ & $\begin{array}{l}\text { Workforce } \\
\text { composition } \\
\text { measures }\end{array}$ & Main findings \\
\hline $\begin{array}{l}\text { Haltiwanger, Lane, } \\
\text { and Spletzer (1999) }\end{array}$ & $\begin{array}{l}\text { USA, 1985-1997, } \\
\text { linked employer } \\
\text { employee data }\end{array}$ & $\begin{array}{l}\text { OLS: pooled levels } \\
\text { 1990 \& 1994, pooled } \\
\text { differences 1986-1990 } \\
\text { \& 1990-1994 with lag } \\
\text { of productivity level }\end{array}$ & $\begin{array}{l}\text { Productivity: log sales } \\
\text { per head }\end{array}$ & $\begin{array}{l}\text { Age: employment } \\
\text { shares }(<30,30-55,>5) \\
\text { Women: employment } \\
\text { share }\end{array}$ & $\begin{array}{l}\text { Age: negative for levels, } \\
\text { positive for differences } \\
\text { Women: negative but not } \\
\text { significant for differences }\end{array}$ \\
\hline $\begin{array}{l}\text { Grund and } \\
\text { Westergaard- } \\
\text { Nielsen (2008) }\end{array}$ & $\begin{array}{l}\text { Denmark, 1992-1997, } \\
\text { linked employer } \\
\text { employee data }\end{array}$ & $\begin{array}{l}\text { OLS: pooled, fixed } \\
\text { effects } \\
\text { GMM: dynamic } \\
\text { model with first lag of } \\
\text { productivity }\end{array}$ & $\begin{array}{l}\text { Productivity: log value } \\
\text { added per head }\end{array}$ & $\begin{array}{l}\text { Age: mean } \\
\text { Women: employment } \\
\text { share }\end{array}$ & $\begin{array}{l}\text { Age: inverse u-shape (max at } \\
\text { age } 37 \text { ) } \\
\text { Women: negative }\end{array}$ \\
\hline $\begin{array}{l}\text { Lallemand and } \\
\text { Rycx (2009) }\end{array}$ & $\begin{array}{l}\text { Belgium, } 1995 \text { \& 2003, } \\
\text { linked employer } \\
\text { employee data }\end{array}$ & OLS for cross sections & $\begin{array}{l}\text { Productivity: log value } \\
\text { added per head }\end{array}$ & $\begin{array}{l}\text { Age: employment } \\
\text { shares }(<30,30-49 \text {, } \\
>49)\end{array}$ & Age: negative \\
\hline $\begin{array}{l}\text { Liu, Tsou, and Wang } \\
\text { (2010) }\end{array}$ & $\begin{array}{l}\text { Taiwan, 1998-2003, } \\
\text { linked employer } \\
\text { employee data }\end{array}$ & $\begin{array}{l}\text { OLS: pooled, fixed } \\
\text { effects }\end{array}$ & $\begin{array}{l}\text { Productivity: log } \\
\text { sales per head, Solow } \\
\text { residual, Levinsohn- } \\
\text { Petrin }\end{array}$ & $\begin{array}{l}\text { Age: employment } \\
\text { shares }(<30,30-55,>55) \\
\text { Women: employment } \\
\text { share (of men) }\end{array}$ & $\begin{array}{l}\text { Age: inverse u-shape } \\
\text { Women: negative }\end{array}$ \\
\hline $\begin{array}{l}\text { Parrotta, Pozzoli, } \\
\text { and Pytlikova (2010) }\end{array}$ & $\begin{array}{l}\text { Denmark, 1995-2005, } \\
\text { linked employer } \\
\text { employee data }\end{array}$ & OLS: pooled, IV & $\begin{array}{l}\text { Productivity: log total } \\
\text { factor productivity }\end{array}$ & $\begin{array}{l}\text { Age: employment } \\
\text { shares }(<33,33-41 \text {, } \\
42-50,>50) \\
\text { Women: employment } \\
\text { share (of men) }\end{array}$ & $\begin{array}{l}\text { Age: inverse u-shape } \\
\text { Women: negative }\end{array}$ \\
\hline Dostie (2011) & $\begin{array}{l}\text { Canada, 1999-2005, } \\
\text { linked employer } \\
\text { employee data }\end{array}$ & OLS & $\begin{array}{l}\text { Productivity: log value } \\
\text { added, Levinsohn- } \\
\text { Petrin }\end{array}$ & $\begin{array}{l}\text { Age: employment } \\
\text { shares }(<35,35-54 \text {, } \\
>54)\end{array}$ & $\begin{array}{l}\text { Age: positive concave, inverse } \\
\text { u-shape }\end{array}$ \\
\hline $\begin{array}{l}\text { Vandenberghe } \\
\text { (2011a) }\end{array}$ & $\begin{array}{l}\text { Belgium, 1998-2006, } \\
\text { linked employer } \\
\text { employee data }\end{array}$ & $\begin{array}{l}\text { OLS: pooled, first } \\
\text { difference } \\
\text { GMM: first difference, } \\
\text { second and third lags } \\
\text { as instruments }\end{array}$ & $\begin{array}{l}\text { Productivity: log value } \\
\text { added per head }\end{array}$ & $\begin{array}{l}\text { Age, women: separate } \\
\text { employment shares } \\
\text { (18-29,30-49, 50-64) } \\
\text { for men and women }\end{array}$ & $\begin{array}{l}\text { Age: negative } \\
\text { Women: negative }\end{array}$ \\
\hline $\begin{array}{l}\text { Vandenberghe } \\
\text { (2011b) }\end{array}$ & $\begin{array}{l}\text { Belgium, 1998-2006, } \\
\text { linked employer } \\
\text { employee data }\end{array}$ & $\begin{array}{l}\text { OLS: pooled, first } \\
\text { difference } \\
\text { GMM: first difference, } \\
\text { second and third lags } \\
\text { as instruments }\end{array}$ & $\begin{array}{l}\text { Productivity: log value } \\
\text { added per head, } \\
\text { Levinsohn-Petrin } \\
\text { Labor costs } \\
\text { per employee, } \\
\text { productivity-labor } \\
\text { cost ratio }\end{array}$ & $\begin{array}{l}\text { Women: employment } \\
\text { share }\end{array}$ & $\begin{array}{l}\text { Women: negative; women } \\
\text { are rather overpaid relative to } \\
\text { their productivity }\end{array}$ \\
\hline
\end{tabular}




\begin{tabular}{|c|c|c|c|c|c|}
\hline Study & Country, years, data & Estimation methods & $\begin{array}{l}\text { Firm performance } \\
\text { indicators }\end{array}$ & $\begin{array}{l}\text { Workforce } \\
\text { composition } \\
\text { measures }\end{array}$ & Main findings \\
\hline $\begin{array}{l}\text { Cataldi, } \\
\text { Kampelmann, } \\
\text { and Rycx (2011) }\end{array}$ & $\begin{array}{l}\text { Belgium, 1999-2006, } \\
\text { linked employer } \\
\text { employee data }\end{array}$ & $\begin{array}{l}\text { OLS: pooled, first } \\
\text { difference GMM: first } \\
\text { difference, second lags } \\
\text { as instruments }\end{array}$ & $\begin{array}{l}\text { Productivity: log value } \\
\text { added per hour }\end{array}$ & $\begin{array}{l}\text { Age: employment } \\
\text { shares }(<30,30-50 \text {, } \\
>50)\end{array}$ & $\begin{array}{l}\text { Age: positive concave for } \\
\text { pooled OLS, negative after age } \\
50 \text { for first difference OLS, not } \\
\text { significant in GMM }\end{array}$ \\
\hline $\begin{array}{l}\text { P. Ilmakunnas } \\
\text { and S. Imakunnas } \\
\text { (2011) }\end{array}$ & $\begin{array}{l}\text { Finland, 1995-2004, } \\
\text { linked employer } \\
\text { employee data }\end{array}$ & $\begin{array}{l}\text { OLS: pooled, fixed } \\
\text { effectsGMM: system, } \\
\text { dynamic models with } \\
\text { first lag of productivity }\end{array}$ & $\begin{array}{l}\text { Productivity: log total } \\
\text { factor productivity, log } \\
\text { value added per hour }\end{array}$ & $\begin{array}{l}\text { Age: mean, } \\
\text { employment shares } \\
(<31,31-50,>50) \\
\text { Women: employment } \\
\text { share }\end{array}$ & $\begin{array}{l}\text { Age: negative Women: } \\
\text { significantly negative only in } \\
\text { pooled OLS }\end{array}$ \\
\hline $\begin{array}{l}\text { Cardoso, } \\
\text { Guimarares, and } \\
\text { Varejao (2011) }\end{array}$ & $\begin{array}{l}\text { Portugal, 1986-2008, } \\
\text { linked employer } \\
\text { employee data }\end{array}$ & $\begin{array}{l}\text { OLS: pooled, fixed } \\
\text { effects GMM: first } \\
\text { difference, second } \\
\text { and third lags as } \\
\text { instruments }\end{array}$ & $\begin{array}{l}\text { Productivity: log sales } \\
\text { per hour }\end{array}$ & $\begin{array}{l}\text { Age: employment } \\
\text { shares ( } 5 \text { year } \\
\text { grouping) Women: } \\
\text { employment share }\end{array}$ & $\begin{array}{l}\text { Age: inverse u-shape for } \\
\text { pooled OLS (max at age 40- } \\
\text { 44), negative for fixed effects } \\
\text { OLS after age } 35 \text {, and positive } \\
\text { concave for GMM until age } 50 \\
\text { Women: significantly negative } \\
\text { for OLS (pooled and fixed } \\
\text { effects), but not significantly } \\
\text { positive for GMM }\end{array}$ \\
\hline $\begin{array}{l}\text { van Ours and } \\
\text { Stoeldraijer (2011) }\end{array}$ & $\begin{array}{l}\text { Netherlands, 2000- } \\
\text { 2005, linked employer } \\
\text { employee data } \\
\text { (manufacturing) }\end{array}$ & $\begin{array}{l}\text { OLS: pooled, first } \\
\text { difference GMM: } \\
\text { first difference, at } \\
\text { least second lags as } \\
\text { instruments }\end{array}$ & $\begin{array}{l}\text { Productivity: Iog value } \\
\text { added per head }\end{array}$ & $\begin{array}{l}\text { Age: employment } \\
\text { shares }(<25,5 \text { year } \\
\text { grouping, }>56) \\
\text { Women: employment } \\
\text { share }\end{array}$ & $\begin{array}{l}\text { Age: inverse u-shape for } \\
\text { pooled OLS (max at age } \\
\text { 35-39), not significant for } \\
\text { first difference OLS, and } \\
\text { positive concave for GMM } \\
\text { Women: significantly negative } \\
\text { for pooled OLS, but not } \\
\text { significant for first difference } \\
\text { OLS, not significantly positive } \\
\text { for GMM }\end{array}$ \\
\hline $\begin{array}{l}\text { Göbel and Zwick } \\
\text { (2012) }\end{array}$ & $\begin{array}{l}\text { Germany, 1997-2005, } \\
\text { linked employer } \\
\text { employee data (LIAB: } \\
\text { manufacturing and } \\
\text { service) }\end{array}$ & $\begin{array}{l}\text { OLS: pooled GMM: } \\
\text { difference, dynamic } \\
\text { models with first } \\
\text { and second lags of } \\
\text { productivity }\end{array}$ & $\begin{array}{l}\text { Productivity: log value } \\
\text { added per head }\end{array}$ & $\begin{array}{l}\text { Age: employment } \\
\text { shares ( } 5 \text { year } \\
\text { grouping) Women: } \\
\text { employment share }\end{array}$ & $\begin{array}{l}\text { Age: inverse U-shape in } \\
\text { manufacturing sectors for OLS, } \\
\text { but not significant in service } \\
\text { sectors and for GMM Women: } \\
\text { negative in manufacturing, } \\
\text { but not significant in service } \\
\text { sectors for OLS and for GMM }\end{array}$ \\
\hline
\end{tabular}




\section{Acknowledgements}

This paper is part of the project KombiFiD - Kombinierte Firmendaten für Deutschland, which is financially supported by the German Ministry for Education and Research (BMBF). It is a joint project of the Institute of Economics of Leuphana University Lueneburg, the research data centers of the German Federal Statistical Office and the statistical offices of the German federal states, the Institute of Employment Research of the Federal Employment Agency and the research department of the German Central Bank. While members of the KombiFiD-team from all institutions contributed to the construction of the dataset used in this paper, we alone are responsible for the study presented here and the conclusions drawn. We thank Alexander Vogel for help with the data. For details on how to access the KombiFiD data, see www. kombifid.de. To facilitate replication, the Stata do-file is available from the authors on request. Pfeifer thanks the VolkswagenStiftung for financial support.

\section{Endnotes}

1 A paper by Lallemand, Plasman, and Rycx (2003), who focus on the effects of wage dispersion on the performance of Belgian firms, provides an appendix table (page 28) with results of OLS regressions for profits (gross operating surplus) per employee. The employment share of women is negatively correlated with profits, and the employment shares of broad age categories $(<25,25-50,>50$ years $)$ seem to have an inverse $u$-shape effect.

2 Data are for legal units (enterprises, or Unternehmen), not for local production units (establishments, or Betriebe). In this paper, we use the term "firm" as a synonym for enterprise.

3 For details, see the quality report for the cost structure survey published by the Federal Statistical Office available at: http://www.destatis.de/jetspeed/ portal/cms/Sites/destatis/Internet/DE/Content/ Publikationen/Qualitaetsberichte/VerarbeitendesGewerbeIndustrie/Kostenstruktur,property=file.pdf

4 See the International Study Group on Exports and Productivity (ISGEP) (2008) for a comparison of results for productivity differentials between exporting and non-exporting firms based on sales per employee, value added per employee and total factor productivity. The results proved remarkably robust.
5 Note that the dataset does not have any information on the capital stock or the sum of assets or equity of the firm, so it is not possible to construct profit indicators based thereon such as return on assets or return on equity.

6 For an introduction to the Establishment History Panel, see Spengler (2008); a detailed description of the current version can be found in Hethey-Maier and Seth (2010).

7 "All employees who are subject to at least one of the following compulsory insurances are liable to social security: health insurance, long-term care insurance, pension insurance, unemployment and accident insurance. However, not liable to social security and thus not included in the data are civil servants, conscripts, those doing alternative civilian service, self-employed, judges, scholars, students, pensioners, clergy and others." (Spengler 2008, p. 502)

8 Note that this information on the diversity of the employees is not available in greater detail; for example, the number of female employees aged 30 to 34 with a university degree is not available from the data (although it would be possible to compute this figure from the individual level information available).

9 Access to the data is easy and costless (for details, see $w w w . k o m b i f i d . d e)$. The data are of high quality, and participation of the enterprises in the cost structure survey and in the delivery of information on the employees covered by social security is mandated. Instead of opinions and "guesstimates" collected in surveys with voluntary participation, the KombiFiDData have reliable information on variables such as value added per head and the rate of turnover profitability. Such data are difficult to collect in interviews or questionnaires without mandatory participation. Therefore, the KombiFiD-Data should at least be carefully looked at by researchers from various fields in economics (including labor economics, industrial organization and international economics) interested in working with firm level data.

10 The sample is limited to firms from West Germany. There are large differences between enterprises from West Germany and the former communist East Germany, even many years after the unification in 1990. Therefore, an empirical study should be performed separately for both parts of Germany. The KombiFiD 
Agreement Sample for East German manufacturing firms, however, contains only a small number of firms. This sample was found not to be representative for the population of firms in a replication study that compares results based on the complete cost structure survey data and data from the KombiFiD Agreement Sample (see Wagner 2012).

11 Firms with incomplete information for any variable in at least one year were dropped from all computations because, by construction, there are no entries because the firms taking part in the cost structure survey were sampled before the start of the survey in 2003. Moreover, exits cannot be identified because firms with information in, say, 2003 but not in 2004 may have closed down, may have relocated out of manufacturing (or out of Germany) or may have shrunk below the cut-off point relevant for the coststructure survey.

12 As a robustness check, all models were re-estimated with logs instead of levels of the dependent variables. Because our variables for productivity and profitability can take non-positive values, the number of observations is reduced by 37 for productivity and by 2073 for profitability in the log specifications. The results, however, remain robust. To conserve space, the results are not reported here but are available from the corresponding author on request.

13 As a robustness check, all models were re-estimated with an additional squared term of the female share. The estimates were not significantly affected. The coefficients of the squared terms are non-significant, whereas the coefficients of the linear terms maintain their size and significance. It should, however, be kept in mind that the mean female employment share is approximately 30 percent across all firms in our sample and that most manufacturing firms have a male dominated workforce. Consequently, our sample does not allow drawing conclusions about female dominated workforces and further increases of the female employment share. To conserve space, the results are not reported here but are available from the corresponding author on request.

14 The reference category in our regression models is the share of employees who are either known not to be medium or highly qualified employees or whose qualification level is not reported in the data and which is, therefore, unknown.
15 As a robustness check, all models were estimated with the median age of the employees and its squared value instead of the shares of employees for various age groups. The results for the other variables in the empirical model did not reveal a different picture. To conserve space, the results are not reported here but are available from the corresponding author on request.

16 As a robustness check, we also performed OLS regressions for the four separate years. These regressions did not show noteworthy differences. To conserve space, the results are not reported here but are available from the corresponding author on request.

17 The breakdown point of an estimator is the highest fraction of outliers an estimator can withstand, and it is a popular measure of robustness.

18 Computations were done using the ado-files provided by Verardi and Croux (2009) with the efficiency parameter set at 0.7 , as suggested based on a simulation study; details are available on request. As a further robustness check, all models were estimated using quantile regression at the median as well. While no convergence was achieved in the profitability estimation for model 2, the results from the other model were very similar to the results from the other estimation methods reported below. Details are available from the corresponding author on request.

19 The effects might seem small at first glance. If we compute relative effects (coefficients divided by the mean of the dependent variable), the size of the coefficients also has economic relevance. For example, a coefficient of 0.1 is a relative effect of approximately $0.1 / 8=1.25 \%$, i.e., a ten percentage point increase in an employment share is correlated with a 12.5 percent higher rate of profit. 
